\title{
Obituary
}

Takesi Nagata, professor emeritus of the National Institute of Polar Research in Tokyo, died on 3 June 1991. Born 24 June 1913 in Komoro, he graduated from Tokyo Imperial University (now called the University of Tokyo) in 1936 and received his DSc in 1944 with his pioneering work on the acquisition mechanism of the thermo-remanent magnetization of volcanic rocks, which later contributed to the revival of the theory of continental drift. In June 1952 Nagata was appointed the secretary of the Japanese National Committee for the International Geophysical Year. He was subsequently the leader of the first three Japanese Antarctic Expeditions, which, among other scientific achievements, established Syowa Station.

Nagata became a member of the Scientific Committee on Antarctic Research (SCAR) when it was established in 1957, and was the national delegate for Japan for more than two decades. He was the chairman of SCAR's Working Group on Geomagnetism and, subsequently, on Upper Atmosphere Physics. He was Vice President of SCAR from 1972-76, and was elected an Honorary Member in 1984. When the National Institute of Polar Research was established in 1973, Nagata was appointed its director general. His more than 400 papers and his scientific achievements earned him many honours and prizes, including the Japan Academy Prize and the Order of Culture. In addition, two mountains have been named after him, one a seamount in the Pacific Ocean, and the other in Victoria Land, Antarctica.

Beau Riffenburgh

Arne Noe-Nygaard, eminent Danish geologist, died on 3 June 1991 at the age of 82 . Born on 30 July 1908, in Ribe, Jutland, Noe-Nygaard became fascinated at a young age with the geology and mineralogy of the north, particularly of Greenland, Iceland, and the Faeroe Islands. While a student at the University of Copenhagen, he spent a great deal of time doing field work in Greenland, participating in the Danish East Greenland Expedition (1929) and the Godthaab Expedition (1930) before spending 21 months (1931-32) in Canning Land in east Greenland. From his base at Vimmelskaftet at Cape Brown, he collected metamorphic eruptive rocks, his investigations of which led to his doctoral dissertation, which was completed in 1937.

In 1942 Noe-Nygaard became the professor of mineralogy at the University of Copenhagen, and it is from that position that in the next two decades he led the effort to establish a permanent geological survey concerned solely with Greenland. The Danish Parliament's passing in 1965 of the legislation necessary to establish the Geological
Survey of Greenland owed a great deal to Noe-Nygaard's vision, influence, and dedication. In 1969 he became the professor of dynamic geology at the University of Copenhagen, as well as the director of the Mineralogical Museum, posts that he held until his retirement in 1978.

\section{Beau Riffenburgh}

Contra-almirante Rodolfo N. M. Panzarini, a former Director of the Instituto Antártico Argentino, died on 28 January 1992. In overall command of Argentine operations in the Antarctic summers 1950-51 and 1952-53, Panzarini was Director of the Institute 1958-68, during which time he built up its reputation for scientific research. He attended the second meeting of the Scientific Committee for Antarctic Research (SCAR) in August 1968. From October of that year he became the first Permanent Delegate for Argentina and a regular attender, representing his country's interests in the Working Groups on Geodesy and Cartography, Geology, Logistics and Oceanography. From 1962 he served two three-year terms as Vice-President of SCAR: on his retirement in 1968, in deep appreciation of his services to Antarctic science, he was elected an Honorary Member of SCAR. In 1969 he received the Patron's Medal of the Royal Geographical Society of Great Britain in recognition of his 'many distinguished services to geographical and allied science during the past quarter of a century'.

\section{Peter Clarkson}

Lt Gen Mark Ivanovich Shevelev, doyen of Soviet Arctic fliers, died on 6 October 1991 aged 86. After gaining some experience of Arctic work when helping to run convoys into the Kara Sea in the late 1920s, in 1932 he was invited to join the newly-formed Chief Administration of the Northern Sea Route(Glavsevmorput') as Deputy Director and head of the Administration of Polar Aviation. In 1937 he played a key role in establishing the first polar drifting station, led by I. D. Papanin, on the sea ice near the North Pole. For this he was awarded the title Hero of the Soviet Union. After World War II he continued to work for the air wing of Glavsevmorput'; he organized for example the early flights from Moscow to Antarctica and the ice reconnaisance flights along the Northern Sea Route. Shevelev was a very popular figure in the polar community. It was said that in the dark years of Stalinist repression he never allowed any measures to be taken against any of the men under his command - an achievement requiring great courage.

Terence Armstrong 